\title{
Teknik Tutur Guru yang Bermuatan Motivasi dalam Interaksi Pembelajaran
}

\author{
Wevi Lutfitasari ${ }^{1}$, Imam Suyitno ${ }^{1}$, Martutik ${ }^{1}$ \\ ${ }^{1}$ Pendidikan Bahasa Indonesia-Universitas Negeri Malang
}

\begin{tabular}{l}
\hline \hline INFO ARTIKEL \\
\hline Riwayat Artikel: \\
Diterima: 16-07-2019 \\
Disetujui: $15-11-2019$ \\
\hline
\end{tabular}

Kata kunci:

speech technique; motivation;

learning interactions;

teknik tutur;

motivasi;

interaksi pembelajaran

\begin{abstract}
ABSTRAK
Abstract: This study aims to describe teacher's specch motivation technique in learning interaction. The method used in this study is refer and extralingual equivalent. The refer method is used to obtain research data. The extralingual equivalent method is used for data analysis. There are two findings presented in this study. Frist, the speech technique used by the teacher to motivation is giving questions for students with mention of student names, singular pronouns, mentioning word to designate more then one person. Secound, the speech technique of attract attention of students by the teacher is speech sung, information, commands, and analogy for student.
\end{abstract}

\begin{abstract}
Abstrak: Penelitian ini bertujuan untuk memaparkan teknik tutur guru ketika memotivasi siswa melalui interkasi pembelajaran. Metode yang digunakan berupa metode simak dan padan ekstarlingual. Metode simak digunakan untuk pemerolehan data penelitian. Metode padan ekstralingual digunakan untuk analisis data. Ada dua hasil temuan yang dipaparkan dalam penelitian ini. Pertama, teknik tutur guru untuk memotivasi siswa berupa pemberian pertanyaan dengan penunjukan langsung, penyebutan nama, kata ganti orang kedua tunggal, dan penyebutan orang kedua jamak. Kedua, teknik tutur penarikan perhatian siswa oleh guru. Teknik tutur penarikan perhatian diwujudkan guru dalam tuturan yang dinyanyikan, penyampaian informasi faktual, perintah, dan penganalogian.
\end{abstract}

\section{Alamat Korespondensi:}

Wevi Lutfitasari

Pendidikan Bahasa Indonesia

Universitas Negeri Malang

Jalan Semarang 5 Malang

E-mail: adhiwevi@gmail.com

Guru menjadi figur penting untuk menentukan kelancaran komunikasi dalam interkasi pembelajaran. Interaksi pembelajaran merupakan hubungan dua arah yang melibatkan keaktifan guru dan siswa untuk pencapaian tujuan pembelajaran (Ardayani, 2017). Pemilihan bahasa sebagai alat komunikasi menjadi unsur yang harus diperhatikan oleh guru dalam interaksi tersebut. Artinya, bahasa yang dituturkan guru harus memeiliki karakteristik edukatif baik dari segi struktural maupun fungsional. Salah satu wujud edukatif tuturan guru dapat ditinjau berdasarkan fungsinya untuk memotivasi siswa. Motivasi dalam lingkup pembelajaran diartikan sebagai dorongan dan penyadaran untuk siswa. Peran guru sebagai motivator diperlukan untuk membentuk sikap belajar siswa, sehingga pembelajaran dapat berjalan secara optimal. Dengan demikian, keberhasilan pembelajaran dapat ditentukan dari teknik tutur guru yang bermuatan motivasi melalui interaksi pembelajaran.

Teknik tutur guru yang bermuatan motivasi didasarkan atas cara guru dalam memotivasi siswa melalui tuturan ketika pembelajaran berlangsung. Ada dua tindakan verbal sebagai indikator dari teknik tutur yang digunakan guru dalam menjalin interkasi dengan siswa, yaitu teknik tutur pemberian pertanyaan dan teknik tutur penarikan perhatian. Pertama, pemberian pertanyaan dijadikan guru sebagai teknik tutur yang dibangun untuk memotivasi siswa melalui interkasi pembelajaran. Kedua, penarikan perhatian dijadikan teknik tutur guru untuk memotivasi siswa dalam interkasi pembelajaran. Kendala tersebut mengindikasikan pentingnya penarikan perhatian siswa melalui teknik tutur yang diterapkan guru. Selain itu, upaya penarikan perhatian dijadikan guru sebagai cara untuk berinteraksi dengan siswa. Teknik tutur tersebut sebagai wujud motivasi oleh guru terhadap siswa dalam menciptakan pembelajaran yang kondusif.

Dua pertimbangan dasar sebagai acuan pentingnya penelitian ini. Pertama, penelitian ini dilakukan untuk mengetahui karakteristik teknik tutur guru mata pelajaran untuk UN (Bahasa Indonesia, Bahasa Inggris, IPA, dan Matematika) yang bermuatan motivatif dalam interaksi pembelajaran. Kedua, tinjauan teknik tutur guru mata pelajaran untuk UN yang bermuatan motivasi penting dilakukan sebagai wujud keterlibatan guru dalam penentuan keberhasilan pembelajaran. Penentuan tersebut didasarkan atas alokasi waktu mengajar guru UN lebih banyak sehingga kerap menjalin interaksi dengan siswa melalui pembelajaran. 


\section{METODE}

Penelitian ini dikategorikan sebagai penelitian kualitatif dengan jenis wacana kelas. Lokasi penelitian ini berada di lembaga MTs Islamiyah Songgon yang terletak di Jalan Ahmad Yani 04, Kelurahan Songgon, Kecamatan Songgon, Kabupaten Banyuwangi, Jawa Timur. Data dalam penilitian ini berupa tutur yang dilengkapi tindakan nonverbal guru ketika memotivasi siswa dalam interaksi pembelajaran. Sumber data dalam penelitian ini adalah guru mata pelajaran untuk UN (Bahasa Indonesia, Bahasa Inggris, IPA, dan Matematika). Pengumpulan data dalam penelitian ini menggunakan teknik sadap yang ditempuh melalui lima tahap, yaitu tahap perekaman data, tahap pentranskripsian data, tahap pengumpulan data hasil transkripsi, tahap seleksi data, dan tahap penampungan data. Analisis data penelitian ini dilakukan melalui empat tahapan, yaitu klasifikasi data, pengkodean data, penyajian data, dan penarikan kesimpulan. Berikut instrumen pengumpulan data dan analisis data yang digunakan dalam penelitian ini.

Tabel 1. Instrumen Pengumpulan Data untuk Penampung Teknik Tutur Guru yang Bermuatan Motivasi

\begin{tabular}{|c|c|c|c|c|c|c|}
\hline No. & $\begin{array}{l}\text { Teknik Tutur } \\
\text { Bermuatan Motivasi }\end{array}$ & $\begin{array}{l}\text { Indikator Teknik Tutur } \\
\text { Bermuatan Motivasi }\end{array}$ & & Sumber Data & Wujud Verbal & Wujud Nonverbal \\
\hline \multirow[t]{4}{*}{1.} & $\begin{array}{l}\text { Teknik tutur } \\
\text { Pemberian Pertanyaan }\end{array}$ & $\begin{array}{l}\text { 1) Teknik tutur melalui } \\
\text { pemberian } \\
\text { pertanyaan yang } \\
\text { ditujukan untuk salah } \\
\text { satu siswa } \\
\text { 2) } \text { Teknik tutur melalui } \\
\text { pemberian } \\
\text { pertanyaan yang } \\
\text { ditujukan untuk }\end{array}$ & (1) & $\begin{array}{l}\text { Guru mata } \\
\text { pelajaran } \\
\text { Matematika }\end{array}$ & Tuturan Guru & $\begin{array}{l}\text { (1) Partisipan: } \\
\text { (2) Tindakan guru: } \\
\text { (3) Waktu dan } \\
\text { tempat } \\
\text { pembelajaran: } \\
\text { (4) Topik } \\
\text { pembicaraan: } \\
\text { (5) Tujuan } \\
\text { pembicaraan }\end{array}$ \\
\hline & & seluruh siswa & (2) & $\begin{array}{l}\text { Guru mata } \\
\text { pelajaran Bahasa } \\
\text { Indoensia }\end{array}$ & Tuturan Guru & $\begin{array}{l}\text { (1) Partisipan: } \\
\text { (2) Tindakan guru: } \\
\text { (3) Waktu dan } \\
\text { tempat } \\
\text { pembelajaran: } \\
\text { (4) Topik } \\
\text { pembicaraan: } \\
\text { (5) Tujuan } \\
\text { pembicaraan }\end{array}$ \\
\hline & & & (3) & $\begin{array}{l}\text { Guru mata } \\
\text { pelajaran Bahasa } \\
\text { Inggris }\end{array}$ & Tuturan Guru & $\begin{array}{l}\text { (1) Partisipan: } \\
\text { (2) Tindakan guru: } \\
\text { (3) Waktu dan } \\
\text { tempat } \\
\text { pembelajaran: } \\
\text { (4) Topik } \\
\text { pembicaraan: } \\
\text { (5) Tujuan } \\
\text { pembicaraan }\end{array}$ \\
\hline & & & (4) & $\begin{array}{l}\text { Guru mata } \\
\text { pelajaran IPA }\end{array}$ & Tuturan Guru & $\begin{array}{l}\text { (1) Partisipan: } \\
\text { (2) Tindakan guru: } \\
\text { (3) Waktu dan } \\
\text { tempat } \\
\text { pembelajaran: } \\
\text { (4) Topik } \\
\text { pembicaraan: } \\
\text { (5) Tujuan } \\
\text { pembicaraan } \\
\end{array}$ \\
\hline 2. & $\begin{array}{l}\text { Teknik tutur } \\
\text { Penarikan Perhatian }\end{array}$ & $\begin{array}{l}\text { 1) Pemberian informasi } \\
\text { oleh guru kepada } \\
\text { siswa } \\
\text { 2) Pemberian arahan } \\
\text { oleh guru kepada } \\
\text { siswa (perintah, } \\
\text { nyanyian, dan } \\
\text { penganalogian) }\end{array}$ & (1) & $\begin{array}{l}\text { Guru mata } \\
\text { pelajaran } \\
\text { Matematika }\end{array}$ & Tuturan Guru & $\begin{array}{l}\text { (1) Partisipan: } \\
\text { (2) Tindakan guru: } \\
\text { (3) Waktu dan } \\
\text { tempat } \\
\text { pembelajaran: } \\
\text { (4) Topik } \\
\text { pembicaraan: } \\
\text { (5) Tujuan } \\
\text { pembicaraan }\end{array}$ \\
\hline
\end{tabular}




\begin{tabular}{|c|c|c|c|c|}
\hline (2) & $\begin{array}{l}\text { Guru mata } \\
\text { pelajaran Bahasa } \\
\text { Indoensia }\end{array}$ & Tuturan Guru & $\begin{array}{l}\text { (1) } \\
(2) \\
(3) \\
(4) \\
(5)\end{array}$ & $\begin{array}{l}\text { Partisipan: } \\
\text { Tindakan guru: } \\
\text { Waktu dan } \\
\text { tempat } \\
\text { pembelajaran: } \\
\text { Topik } \\
\text { pembicaraan: } \\
\text { Tujuan } \\
\text { pembicaraan }\end{array}$ \\
\hline (3) & $\begin{array}{l}\text { Guru mata } \\
\text { pelajaran Bahasa } \\
\text { Inggris }\end{array}$ & Tuturan Guru & $\begin{array}{l}\text { (1) } \\
(2) \\
(3) \\
(4) \\
(5)\end{array}$ & $\begin{array}{l}\text { Partisipan: } \\
\text { Tindakan guru: } \\
\text { Waktu dan } \\
\text { tempat } \\
\text { pembelajaran: } \\
\text { Topik } \\
\text { pembicaraan: } \\
\text { Tujuan } \\
\text { pembicaraan }\end{array}$ \\
\hline (4) & $\begin{array}{l}\text { Guru mata } \\
\text { pelajaran IPA }\end{array}$ & Tuturan Guru & $\begin{array}{l}\text { (1) } \\
\text { (2) } \\
(3) \\
\text { (4) } \\
\text { (5) }\end{array}$ & $\begin{array}{l}\text { Partisipan: } \\
\text { Tindakan guru: } \\
\text { Waktu dan } \\
\text { tempat } \\
\text { pembelajaran: } \\
\text { Topik } \\
\text { pembicaraan: } \\
\text { Tujuan } \\
\text { pembicaraan }\end{array}$ \\
\hline
\end{tabular}

Tabel 2. Instrumen Analisis Data untuk Pengodean Teknik Tutur Guru Bermuatan Motivasi

\begin{tabular}{|c|c|c|c|c|c|c|c|}
\hline No. & $\begin{array}{c}\text { Teknik Tutur } \\
\text { Bermuatan Motivasi }\end{array}$ & & $\begin{array}{l}\text { Indikator Teknik Tutur } \\
\text { Bermuatan Motivasi }\end{array}$ & & Sumber Data & Kode & $\begin{array}{l}\text { Wujud Verbal dan } \\
\text { Nonverbal }\end{array}$ \\
\hline \multirow[t]{4}{*}{1.} & \multirow[t]{4}{*}{$\begin{array}{l}\text { Teknik tutur Pemberian } \\
\text { Pertanyaan }\end{array}$} & \multirow[t]{4}{*}{ 1) } & \multirow{4}{*}{$\begin{array}{l}\text { Teknik tutur melalui pemberian } \\
\text { pertanyaan yang ditujukan } \\
\text { untuk salah satu siswa } \\
\text { Teknik tutur melalui pemberian } \\
\text { pertanyaan yang ditujukan } \\
\text { untuk seluruh siswa }\end{array}$} & (1) & $\begin{array}{l}\text { Guru mata pelajaran } \\
\text { Matematika }\end{array}$ & TTPEE & $\begin{array}{l}\text { a...( TTPEE } 1) \\
\text { b...( TTPEE } 2)\end{array}$ \\
\hline & & & & (2) & $\begin{array}{l}\text { Guru mata pelajaran } \\
\text { Bahasa Indoensia }\end{array}$ & TTPEV & $\begin{array}{l}\text { a....( TTPEV 1) } \\
\text { b....( TTPEV 2) }\end{array}$ \\
\hline & & & & (3) & $\begin{array}{l}\text { Guru mata pelajaran } \\
\text { Bahasa Inggris }\end{array}$ & TTPER & $\begin{array}{l}\text { a....( TTPER } 1) \\
\text { b....( TTPER } 2)\end{array}$ \\
\hline & & & & (4) & Guru mata pelajaran IPA & TTPEA & $\begin{array}{l}\text { a....( TTPEA 1) } \\
\text { b....( TTPEA 2) }\end{array}$ \\
\hline \multirow[t]{4}{*}{2.} & \multirow[t]{4}{*}{$\begin{array}{l}\text { Teknik tutur Penarikan } \\
\text { Perhatian }\end{array}$} & \multirow[t]{4}{*}{ 1) } & \multirow{4}{*}{$\begin{array}{l}\text { Pemberian informasi oleh guru } \\
\text { kepada siswa } \\
\text { Pemberian arahan oleh guru } \\
\text { kepada siswa (perintah, } \\
\text { nyanyian, dan penganalogian) }\end{array}$} & (1) & $\begin{array}{l}\text { Guru mata pelajaran } \\
\text { Matematika }\end{array}$ & TTEPE & $\begin{array}{l}\text { a....( TTEPE } 1) \\
\text { b....( TTEPE } 2)\end{array}$ \\
\hline & & & & (2) & $\begin{array}{l}\text { Guru mata pelajaran } \\
\text { Bahasa Indoensia }\end{array}$ & TTEPV & $\begin{array}{l}\text { a....( TTEPV 1) } \\
\text { b....( TTEPV 2) }\end{array}$ \\
\hline & & & & (3) & $\begin{array}{l}\text { Guru mata pelajaran } \\
\text { Bahasa Inggris }\end{array}$ & TTEPR & $\begin{array}{l}\text { a....( TTEPR1) } \\
\text { b....( (TTEPR 2) }\end{array}$ \\
\hline & & & & (4) & Guru mata pelajaran IPA & TTEPA & $\begin{array}{l}\text { a....( TTEPA } 1) \\
\text { b....( TTEPA } 2)\end{array}$ \\
\hline
\end{tabular}

\section{HASIL}

Hasil analisis teknik tuturan guru ketika membangun interkasi dengan siswa akan dipaparakan dalam subbab ini. Paparan subbab ini bertujuan untuk menilik tindakan verbal guru ketika menjalin interkasi dengan siswa sebagai target motivasi melalui proses pembelajaran. Artinya, hasil penelitian ini mengarah pada pola interaksi yang berpusat pada guru dengan tujuan untuk memotivasi siswa. Pola interaksi yang berpusat pada guru berpengaruh dalam pengontrolan emosi siswa (Karner \& Kristina, 2016). Dengan demikian, pengontrolan tersebut dapat diterapkan melalui dua teknik tutur guru yang bermuatan motivasi. Dua teknik tutur tersebut terdiri atas teknik tutur pemberian pertanyaan dan teknik tutur penarikan perhatian.

\section{Teknik Tutur Pemberian Pertanyaan}

Teknik tutur yang dipaparakan dalam subbab ini adalah cara guru ketika ingin membangun interaksi dengan siswa secara personal maupun kelompok melalui pemberian pertanyaan. Interaksi teresebut bertujuan untuk memotivasi siswa ketika pembelajaran berlangsung. Berikut beberapa data sebagai wujud dari teknik tutur guru melalui tindakan verbal dan nonverbal dalam pembelajaran. 
(1) Guru: "Drama iku opo fajar?" (Tuturan 1)

Guru: "Yang lain diam!" (Tuturan 2)

Guru: “Ayo Fajar drama iku opo?”(Tuturan 3)

Konteks: (Data (1) merupakan wujud tuturan guru mata pelajaran Bahasa

Indonesia yang sedang bertanya kepada salah satu siswa kelas VIII C bernama Fajar melalui pembelajaran tentang drama)

(TTPEV1)

Teknik tutur yang ingin diterapkan guru melalui pemberian pertanyaan dalam pembelajaran tergambar pada data (1). Data tersebut berasal dari tuturan guru mata pelajaran Bahasa Indonesia dengan materi tentang drama yang berlangsung pada tanggal 20 Februari 2019 di kelas VIII C.

Data (1) merupakan teknik tutur guru melalui pemberian pertanyaan kepada siswa. Pemberian pertanyaan yang dibangun pada data (1) berupa pertanyaan yang disampaikan secara berulang oleh guru kepada salah satu siswa bernama Fajar. Perulangan tersebut tampak pada tuturan berbahasa Jawa berupa drama iku opo yang ada pada (Tuturan 1) dan (Tuturan 3). Pemberian pertanyaan tersebut dipertegas dengan perintah untuk menjawab pada kata ayo (Tuturan 3). Artinya, guru menginginkan siswa bernama Fajar untuk merespon pertanyaan yang disampaikan melalui data (1).

Berdasarkan teknik tutur pada data (1) guru ingin memotivasi siswa secara personal khususnya siswa bernama Fajar. Motivasi secara personal tersebut dipertegas pada (Tuturan 2) yang lain diam!. Artinya, perintah tersebut mengisyaratkan bahwa siswa selain Fajar untuk diam dan hanya Fajar yang boleh merespon pertanyaan dari guru. Teknik tutur pada data (1) diperkuat dengan tindakan nonverbal guru yang berbicara sambil berjalan ke arah Fajar dan jari telunjuk sebelah kanan (berada di depan kepala) guru menunjuk ke arah Fajar. Teknik tutur tersebut bertujuan untuk memotivasi siswa bernama Fajar yang sebelumnya ramai agar lebih fokus dalam belajar. Motivasi merupakan dorongan untuk menciptakan prilaku belajar siswa (Dimyati \& Mudjiono, 2013). Ada data lain sebagai teknik tutur guru melalui pemberian pertanyaan kepada siswa. Berikut kutipan data dari teknik tutur tersebut.

(2) Guru: "Dewi, are you oke?" (Tuturan 1)

Guru: "What happen with Dewi?" (Tuturan 2)

Guru: "Because the last meeting berkaitan dengan materi saya dipertemuan kemarin adalah about recount text..." (Tuturan 3)

Guru: “Nah, sebenarnya saya ingin sekali Dewi Ria bercerita, sebab apa yang terjadi dengan Dewi sebenarnya cocok sekali loh dengan pembelajaran ini." (Tuturan 4)

Konteks1: (Data (2) merupakan wujud tuturan guru mata pelajaran Bahasa Inggris yang sedang berinteraksi dengan siswa kelas VIII B melalui pembelajaran tentang pengalaman pribadi)

Konteks2: (Pemberian pertanyaan oleh guru tentang pengalaman salah satu siswa bernama Dewi)

(TTPER1)

Data (2) bagian dari teknik tutur guru dalam pemberian pertanyaan sebagai cara untuk memotivasi siswa. Teknik tutur pada data (2) terjadi dalam pembelajaran Bahasa Inggris dengan materi tentang pengalaman pribadi. Pembelajaran tersebut berlangsung pada tanggal 18 Februari 2019 di kelas VIII B dengan durasi delapan puluh menit.

Data (2) merupakan teknik tutur yang digunakan untuk memotivasi siswa. Teknik tutur pada data (2) di sampaikan guru pada tahap apersepsi atau sebelum pembelajaran di mulai. Teknik tutur yang dibangun guru pada data (2) berupa pemberian pertanyaan berbahasa Inggris. Pertanyaan tersebut untuk salah satu siswa yang disertai penyebutan nama secara personal. Penyebutan nama siswa tergambar dalam (Tuturan 1) pada kata Dewi. Pertanyaan yang diberikan guru tergambar melalui (Tuturan 1) pada kata are yang berarti apakah dan (Tuturan 2) pada kata what atau apa. Pertanyaan tersebut diperkuat dengan tindakan nonverbal dari guru yang berupa pandangan guru ke arah Dewi dan jari telunjuk guru sebelah kanan (posisi berada di depan dada kanan) mengarah ke Dewi ketika sedang bertanya. Artinya, teknik tutur yang diterapkan guru pada data di atas bertujuan untuk memotivasi siswa secara personal khususnya siswa bernama Dewi. Motivasi tersebut bertujuan agar siswa bernama Dewi merespons pertanyaan dari guru untuk menceritakan pengalaman pribadi. Selain itu, pertanyaan dari guru sebagai stimulus agar siswa memahami gambaran awal dari topik dan tujuan pembelajaran yang dipertegas melalui (Tuturan 4). Salah satu wujud motivasi adalah pemberian rumusan tujuan pembelajaran kepada siswa (Sardiman, 2012). Berikut kutipan data sebagai teknik tutur dalam berinteraksi dengan siswa melalui pemberian pertanyaan. Teknik tutur yang dibangun oleh guru pada data di bawah tergolong dalam pembangunan interaksi secara personal.

(3) Guru: "Novi teks tanggapan itu apa?" (Tutruan 1)

Guru: "Teks tanggapan." (Tuturan 2)

Guru: "Kalau tanggapan iku kometar." (Tuturan 3)

Guru: "Kalau teks tanggapan itu apa?” (Tuturan 4)

Guru: "He lihat di buku ada!" (Tuturan 5)

Konteks: (Data (3) merupakan wujud tuturan guru mata pelajaran Bahasa Indonesia yang berupa pemberian pertanyaan kepada salah satu siswa kelas IX B bernama Novi tentang arti dari teks tanggapan melalui interaksi pembelajaran) 
Data (3) merupakan wujud verbal dari teknik tutur guru ketika ingin memotivasi siswa pemberian pertanyaan. Pemberian pertanyaan tersebut bersumber pada tuturan guru mata pelajaran Bahasa Indonesia yang teradapat dalam pembelajaran tentang teks tanggapan. Pembelajaran tersebut berlangsung pada tanggal 23 November 2018 di kelas IX B dengan durasi delapan puluh menit.

Teknik tutur guru pada data (3) dikategorikan sebagai pemberian pertanyaan yang dilakukan dengan mengulang tuturan. Pengulangan tersebut tercermin pada (Tutruan 1) dan (Tuturan 4) yang berupa teks tanggapan itu apa?. Pemberian pertanyaan tersebut ditujukan untuk salah satu siswa bernama Novi. Guru memberikan pertanyaan kepada Novi pada tahap penyampaian materi.

Teknik tutur guru pada data (3) berfungsi untuk memotivasi siswa secara personal melalui pemberian pertanyaan. Pertanyaan guru pada data (3) dipertegas dengan kalimat perintah pada (Tuturan 5) yang berupa kata lihat. Penegasan tersebut untuk mendorong Novi agar merespons pertanyaan dari guru yang disertai intonasi naik ketika menuturkan kalimat tersebut. Teknik tutur guru pada data (3) turut disertai tindakan nonverbal yang berupa pandangan dan jari telunjuk guru mengarah ke Novi ketika menuturkan (Tuturan 1). Dengan demikian, teknik tutur yang ingin diterapkan guru melalui gambaran data (3) dapat dikategorikan sebagai wujud motivasi guru kepada siswa. Guru ingin mendorong siswa agar lebih aktif melalui pertanyaan atau tes lisan mengenai materi pembelajaran yang harus dijawab oleh siswa.

Data di bawah ini merupakan bagian dari wujud teknik tutur guru untuk memotivasi siswa melalui interaksi pembelajaran. Teknik tutur pada data di bawah ini berupa pemberian pertanyaan secara personal yang hanya melibatkan guru dan salah satu siswa.

(4) Guru: "Jadi kesimpulannya teks tanggapan iku apa Lum?” (Tuturan 1)

Guru: "Ulum apa?" (Tuturan 2)

Guru: "Jadi kesimpulan itu apa?" (Tuturan 3)

Guru: "Kalau Ulum nggak tau, iki mau neng kene apa tujuane?" (Tuturan 4)

Guru: "Ulum tak tanyak nggak bisa tapi ada temannya menjawab nggak terima." (Tuturan 5)

Konteks: (Data (4) meruapakan wujud tuturan guru mata pelajaran Bahasa Indonesia yang berupa pemberian pertanyaan kepada salah satu siswa kelas IX B bernama ulum tentang kesimpulan dari teks tanggapan melalui interaksi pembelajaran)

(TTPEV3)

Teknik tutur pemberian pertanyaan oleh guru terlihat pada data (4). Teknik tutur tersebut berasal dari guru mata pelajaran Bahasa Indonesia yang memberikan pertanyaan kepada salah satu siswa. Teknik tutur tersebut diterapkan ketika pembelajaran tentang teks tanggapan berlangsung pada 23 November 2018 di kelas IX B dengan durasi delapan puluh menit.

Data (4) merupakan teknik tutur guru dalam memberikan pertanyaan kepada siswa salah satu siswa bernama Ulum. Pemberian pertanyaan tersebut bertujuan untuk memperoleh jawaban dan sebagai teguran oleh guru kepada Ulum. Pemberian pertanyaan dilakukan dengan pengulangan tuturan pada (Tuturan 1) dan (Tuturan 4) berupa kata apa. Pertanyaan tersebut dipertegas dengan teguran guru pada (Tuturan 5) berupa "Ulum tak tanyak nggak bisa tapi ada temannya menjawab nggak terima”. Tuturan tersebut bermaksud untuk memberi penyadaran kepada Ulum agar lebih memahami materi pembelajaran dan menghargai guru yang sedang menjelaskan materi. Dengan demikian, data (4) dikategorikan sebagai teknik tutur guru yang bermuatan motivasi dengan adanya pengaruh positif untuk siswa. Berdasarkan hasil persentasi yang diperoleh dari jawaban siswa di SMP Islam Plus Baitul Maal-Pondok Aren dapat dinyatakan bahwa guru perlu memberikan teguran ketika siswa melakukan pelanggaran (Marstiyaningtiyas, 2014). Ada data lain sebagai teknik tutur yang ingin ditunjukkan guru kepada siswa melalui pemberian pertanyaan. Berikut kutipan wujud verbal yang dilengkapi penjelasan dari tindakan nonverbal guru ketika bertanya kepada salah satu siswa.

(5) Guru: "Mas, pisang goreng harganya limaratus rupiah belinya lima ribu, oleh piro?" (Tuturan 1)

Guru: "Sepuluh" (Tuturan 2)

Guru: "Kok entok sepoloh darimana?" (Tuturan 3)

Guru: "Kan sederhana tinggal lima ribu dibagi limaratus." (Tuturan 4)

Guru: "Semudah itu, tapi karena sampean terbiasa malas mikir." (Tuturan 5)

Guru: "Mangkne sampean itu harus paham teori dan rumusnya!" (Tuturan 6)

Konteks1: (Data (5) merupakan wujud tuturan guru mata pelajaran Matematika yang bertanya kepada salah satu siswa laki-laki di kelas VII B)

Konteks2: (Pertanyaan guru pada data (5) terjadi ketika guru menyampaikan materi pembelajaran tentang untung dan rugi)

(TTPEE1)

Data (5) merupakan kutipan dari bahasa guru mata pelajaran Matematika yang sedang berinteraksi dengan salah satu siswa laki-laki. Interaksi tersebut berlangsung ketika guru memberi ilustrasi tentang materi untung dan rugi kepada siswa kelas VII B pada tanggal 04 Maret 2019 dengan durasi delapan puluh menit. 
Data (5) merupakan gambaran teknik tutur guru melalui pemberian pertanyaan kepada siswa secara personal. Pertanyaan yang diberikan guru kepada siswa terlihat dari (Tuturan 1) yang berupa oleh piro dan (Tuturan 3) berupa kata darimana. Pertanyaan tersebut ditujukan untuk salah satu siswa sebagai target komunikan yang dibuktikan dengan kata sapaan untuk orang kedua tunggal pada kata mas (Tuturan 1), kata sampean (Tuturan 5), kata sampean (Tuturan 6). Selain itu, penerapan teknik pemberian pertanyaan oleh guru kepada siswa secara personal tersebut diperkuat dengan tindakan nonverbal yang berupa pandangan dan gerakan guru mendekati salah satu bangku siswa laki-laki sambil menuturkan wujud verbal pada data (5). Artinya, teknik tutur guru pada data (5) berfungsi untuk memotivasi siswa secara personal. Motivasi tersebut bersumber pada dorongan dan penyadaran guru kepada siswa. Dorongan guru terlihat melalui kalimat pertanyaan yang disampaikan guru kepada siswa untuk direspon. Penyadaran dari guru untuk siswa terlihat pada (Tuturan 5) berupa sampean terbiasa malas mikir. Ungkapan guru tersebut bermaksud untuk mengkritik salah satu siswa agar mengubah kebiasaan tingkah laku yang kurang baik dalam belajar. Salah satu fungsi diarahkan pada perubahan tingkah laku dari siswa (Hamalik, 2013).

Teknik tutur guru yang berwujud pemberian pertanyaan tidak hanya untuk siswa secara personal namun kolektif.

Berikut data dari teknik tutur guru yang berwujud pemberian pertanyaan untuk seluruh siswa.

(6) Guru: "Hati berfungsi sebagai tempat mengubahnya provitamin A menadi vitamin A." (Tuturan 1)

Guru: "Vitamin A didapat dari mana?" (Tuturan 2)

Guru: "Ha?" (tutruan 3)

Guru: “Vitaman A ini didapat dari mana?" (Tuturan 4)

Guru: "Ayok wes kelas delapan mosok gak iso?" (Tuturan 5)

Guru: "Ha?" (Tuturan 6)

Konteks: (Data (6) merupakan wujud tuturan guru IPA ketika bertanya kepada

seluruh siswa kelas VIII C tentang makanan yang mengandung vitamin A melalui interaksi pembelajaran)

(TTPEA2)

Data (6) merupakan tuturan guru mata pelajaran IPA. Data (6) dijadikan sebagai wujud verbal dari pola interaksi guru yang berlangsung dalam pembelajaran tentang paru-paru pada tanggal 06 Maret 2019 dikelas VIII C. Data (6) merupakan wujud teknik tutur guru ketika ingin berinteraksi dengan siswa melalui pemberian pertanyaan. Pertanyaan tersebut tergambar melalui kumpulan kata dari mana? (Tuturan 2) dan (Tuturan 4), kata ha? (Tuturan 3) dan (Tuturan 6) sebagai kata seru yang berfungsi untuk mempertegas pertanyaan, dan kumpulan kata mosok gak iso? (Tuturan 5). Pertanyaan tersebut ditujukan untuk semua siswa. Hal tersebut tergambar pada segmentasi kalimat kelima berupa ayok wes kelas delapan pada (Tuturan 5). Artinya, teknik tutur guru pada data (6) adalah wujud motivasi untuk semua siswa yang terlibat dalam pembelajaran tersebut. Teknik tutur pada data (6) dipertegas dengan adanya tindakan nonverbal berupa guru berbicara sambil berdiri di depan kelas dan jari tangan kiri memegang LKS yang digerakkan ke depan dan ke belakang (berada di samping wajah guru) dan pandangan ke arah siswa. Dengan demikian, guru memotivasi semua siswa melalui pertanyaan untuk mendorong siswa agar merepson pertanyaan dari guru. Selain itu, pada data (6) guru menegur siswa melalui (Tuturan 5) berupa ayok wes kelas delapan mosok gak iso. Teguran tersebut bertujuan untuk memperngaruhi seluruh siswa agar terdorong dalam merespon pertanyaan dari guru. Motivasi sebagai dorongan untuk siswa dalam beraktivitas yang bersumber pada salah satu rangsang ekternal berupa pengaruh guru (Redondo \& Martin, 2015).

Ada data lain yang menunjukkan teknik tutur guru berupa pemberian pertanyaan kepada siswa. Pertanyaan tersebut sebagai wujud interaksi antara guru dengan siswa secara kolektif.

(7) Guru: "Apa Newton?" (Tuturan 1)

Guru: "Ha?" (Tuturan 2)

Guru: "Apa Newton?" (Tuturan 3)

Guru: "Ha?" (Tuturan 4)

Guru: "Newton kok gerak." (Tuturan 5)

Guru: “Ayo baru kemarin loh!” (Tuturan 6)

Guru: "Eh gorong mari pelajarane." (Tuturan 7)

Guru: “Apa?” (Tuturan 8)

Guru: “Halah paling wingi diterangne turu kabeh.” (Tuturan 9)

Guru: "Mangkne setiap guru menarangkan selalu disimpan di memori!" (Tuturan 10)

Guru: "Memorimu iku lebih dari 16 GB, lek gak mbok gunakan dengan baik eman." (Tuturan 11)

Konteks: (Data (7) merupakan wujud tuutran guru mata pelajaran IPA yang sedang bertanya kepada siswa kelas VIII C tentang Newton melalui interaksi pembelajaran)

(TTPEA3)

Kutipan pada data (7) merupakan salah satu wujud teknik tutur guru melalui pemberian pertanyaan. Pemberian pertanyaan pada data (7) terjadi ketika guru mata pelajaran IPA menjelaskan materi tentang getaran dan gelombang. Materi tersebut disampaikan guru pada tanggal 12 Maret 2019 di kelas VIII C. 
Teknik tutur yang diterapkan guru pada data (7) berupa pemberian pertanyaan kepada siswa kelas VIII C. Gambaran pertanyaan guru pada data (7) berupa kata apa pada (Tuturan 1), (Tuturan 3), (Tuturan 8) dan kata ha (Tuturan 2), (Tuturan 4) sebagai kata seru yang berfungsi untuk mempertegas pertanyaan guru kepada siswa. Pertanyaan tersebut ditujukan untuk seluruh siswa yang tergambar pada (Tuturan 9) berupa kata kabeh. Dengan demikian, pada data (7) guru ingin memotivasi seluruh siswa yang terlibat dalam pembelajaran. Teknik tutur tersebut dilengkapi dengan tindakan nonverbal berupa guru berbicara di depan kelas (berdiri di depan papan tulis) sambil membawa LKS dan pandangan ke arah siswa. Motivasi guru melalui data (7) bertujuan untuk mendorong siswa agar merespon pertanyaan guru. Selain itu, pemberian pertanyaan pada data (7) disertai teguran. Teguran guru tersebut terlihat dalam (Tuturan 9) berupa halah paling wingi diterangne turu kabeh yang bermaksud untuk mengkritik semua siswa yang lupa terhadap materi pembelajaran, sehingga tidak ada yang merepson pertanyaan dari guru.

Berikut data lain yang menunjukkan teknik tutur guru melalui pemberian pertanyan. Permberian pertanyaan oleh guru pada data di bawah ini ditujukan untuk siswa secara keseluruhan.

(8) Guru: "Mrs. Rahma ketika membuka kelas yang ditanyakan seperti ini, what date is it?" (Tuturan 1)

Guru: “Tanggal berapa sekarang?" (Tuturan 2)

Guru: "What date is it?" (Tuturan 3)

Guru: "Tanggal berpaa sekarang?" (Tuturan 4)

Guru: "Nah padahal saya sudah code switching loh and this Indonesia masih tersenyum." (Tuturan 5)

Guru: "Artinya kalian masih ada rasa ketakutan." (Tuturan 6)

Guru: "Padahal saya sudah tiap hari paling tidak setiap minggu wira-wira ke kelas ini lo, tapi masih malu menjawab." (Tuturan 7)

Guru: “Apa masalahnya kalian malu bertanya atu malu menjawab?" (Tuturan 8)

Guru: “Apa masalahanya?" (Tuturan 9)

Guru: "Apa masalahnya?" (Tuturan 10)

Guru: "Jadi tolong ya anak-anak dibiaskan latihan diingat-ingat pelajarannya remembering!" (Tuturan 11)

Konteks: (Data (8) merupakan tuturan guru mata pelajaran Bahasa Inggris yang berupa pemberian pertanyaan kepada siswa kelas VIII B tentang masalah siswa yang takut menjawab pertanyaan dari guru melalui interaksi pembelajaran)

(TTPER2)

Data (8) merupakan teknik tutur guru mata pelajaran Bahasa Inggris yang sedang berinteraksi dengan siswa melalui pemberian pertanyaan. Pertanyaan tersebut diberikan ketika guru menjelaskan materi tentang short message di kelas VIII B pada tanggal 04 Maret 2019 dengan durasi delapan puluh menit.

Teknik tutur pada data (8) dibangun guru melalui pemberian pertanyaan kepada siswa. Pertanyaan guru pada data (8) dibuktikan pada penanda kata what (Tuturan 1 dan Tuturan 3), kata apa (Tuturan 8, Tuturan 9, dan Tuturan 10) dan kata berapa (Tuturan 2 dan Tuturan 4). Pertanyaan tersebut ditujukan untuk seluruh siswa yang terbukti dengan adanya kata kalian (Tuturan 6 dan Tuturan 8) dan kata anak-anak (Tuturan 11). Data (8) dilengkapi tindakan nonverbal berupa guru berbicara di depan kelas sambil berdiri dan jari telunjuk sebelah kanan (berada di depan wajah) menunjuk ke siswa. Dengan demikian, teknik tutur guru pada data (8) bermaksud untuk mendorong siswa agar lebih aktif dalam pembelajaran. Selain itu, maksud dari adanya interaksi pada data (8) adalah teguran dan penguatan untuk siswa agar lebih terlibat aktif dalam belajar. Pemberian peguatan kepada siswa merupakan salah satu peran guru sebagai motivator di kelas (Hikmah, dkk., 2015)(Hikmah, dkk.2015).

Berikut data yang menunjukan teknik tutur guru melalui pemberian pertanyaan. Pertanyaan tersebut ditujukkan unutk seluruh siswa yang terlibat dalam pembelajaran.

(9) Guru: "Ok berkaitan dengan pelajaran saya, apa yang kalian pelajari semalam?" (Tuturan 1)

Guru: "What did you leran?" (Tuturan 2)

Guru: “Apa yang kalian pelajari semalam?” (Tuturan 3)

Guru: "Apakah ada PR?” (Tuturan 4)

Guru: "Karena hari rabu kalian sudah ujian akhir semester, artinya materinya harus diselesaikan sampai latihan di LKS." (Tuturan 5)

Guru: “Apa yang kalian lakukan ketika kan final semester?” (Tuturan 6)

Guru: "Belajar!" (Tuturan 7)

Guru: “Apakah hanya final semester aja kalian belajar?” (Tuturan 8)

Guru: “Apakah belajar saat final semester or kalau hanya ada PR? (Tuturan 9)

Konteks: (Data (9) merupakan tuturan guru mata pelajaran Bahasa Inggris yang berupa pemberian pertanyaan untuk siswa kelas VIII B terkait cara belajar siswa melalui interaksi pembelajaran)

(TTPER3) 
Data (9) merupakan wujud teknik guru mata pelajaran bahasa Inggris. Teknik tersebut digunakan guru untuk berinteraksi dengan siswa dalam pelajaran tentang prepotition of place pada tanggal 24 November 2019 di kelas VIII B dengan durasi depalan puluh menit.

Data (9) merupaka teknik tutur guru yang berwujud pemberian pertanyaan. Pertanyaan tersebut ditandai dengan penggunaan kata apa (Tuturan 1, Tuturan 3, dan Tuturan 6), apakah (Tuturan 4, Tuturan 8, dan Tuturan 9), dan what (Tuturan 2). Pertanyaan pada data (9) ditujukan untuk seluruh siswa yang ditandai dengan tidak ada penyebutan nama dan penunjukan langsung oleh guru. Selaian itu, ada kata you (Tuturan 2) dan kata kalian (Tuturan 1, Tuturan 3, Tuturan 5, Tuturan 6, dan Tuturan 8) pada data (9). Teknik tutur guru pada data (9) dilengkapi tindakan nonverbal berupa guru berbicara di depan kelas sambil duduk dan pandangan ke seluruh siswa sambil jari tangan kiri bergerak-gerak (berada di depan dada). Dengan demikian, teknik tutur pada data di atas berfungsi sebagai alat verbal memotivasi siswa kelas VIII B. Hal tersebut didasarkan atas maksud pertanyaan guru pada data (9) untuk membangkitkan perilaku belajar siswa. Peran guru merupakan salah satu sumber motivasi untuk menciptakan perilaku belajar siswa (Dimyati \& Mudjiono, 2013). Ada data lain yang menunjukkan teknik tutur guru dalam pembelajaran. Teknik tutur tersebut berwujud pemberian pertanyaan kepada seluruh siswa.

(10) Guru: "Yang cowok alur dari drama tadi apa?" (Tuturan 1)

Guru: "Alurnya apa?" (Tuturan 2)

Guru: "Pakai alur apa?" (Tuturan 3)

Guru: "Alur apa?" (Tuturan 4)

Guru: "Ya Allah wes dibahas." (Tuturan 5)

Guru: "Alur apa?" (Tuturan 6)

Guru: "Yang cewek memakai alur apa?" (Tuturan 7)

Guru: "Ya Allah." (Tuturan 8)

Guru: "Alur itu ada maju, mundur, campuran." (Tuturan 9)

Guru: "Drama yang kalian perankan tadi memakai alur apa?" (Tuturan 10)

Guru: "Berarti kalian gak paham." (Tuturan 11)

Konteks: (Data (10) merupakan tuturan guru mata pelajaran Bahasa Indoensia yang berupa pemberian pertanyaan siswa kelas VIII C tentang alur dalam drama melalui interaksi pembelajaran)

(TTPEV4)

Data (10) merupakan wujud teknik tutur guru mata pelajaran Bahasa Indonesia. Teknik tutur tersebut digunakan guru untuk berinteraksi dengan siswa ketika pembelajaran tentang drama berlangsung pada tanggal 13 Maret di kelas VIII C dengan durasi delapan puluh menit.

Data (10) merupakan salah satu wujud verbal dari teknik tutur yang ingin diterapkan guru untuk memotivasi siswa kelas VIII C. Teknik tutur tersebut dibangun melalui pemberian pertanyaan oleh guru kepada seluruh siswa. Tanda dari pemberian pertanyaan oleh guru pada data (10) terdapat pada pengulangan kata alur apa? yang terdapat dalam (Tuturan 1, Tuturan 2, Tuturan 3, Tuturan 4, Tuturan 6, Tuturan 7, dan Tuturan 10). Pertanyaan tersebut ditujuakan untuk seluruh siswa yang ditandai dengan kata cowok (Tuturan 1), kata cewek (Tuturan 6), dan kata kalian (Tuturan 9 dan Tuturan 10). Artinya, pemberian pertanyaan tersebut sebagai motivasi untuk siswa agar mampu menjawab pertanyaan tentang materi yang telah dipelajari. Dengan demikian, pertanyaan dari guru dijadikan sebagai dorongan untuk siswa agar lebih aktif dalam menerima pelajaran melalui respon dari pertanyaan guru. Salah satu wujud motivasi yang dapat diterapkan guru di dalam kelas adalah pemberian tes yang mendorong siswa untuk berkewajiban aktif dalam belajar (Sardiman, 2012).

Berikut ini kutipan data yang menunjukkan teknik tutur guru dalam pembelajaran. Interaksi yang dibangun pada data di bawah ini melalui pemberian pertanyaan.

(11) Guru: "Sudah diaksih tau sama Pak Yunus tentang estimasi ulangan nasional?" (Tuturan 1)

Guru: "April sudah mulai ujian-ujian persiapan kalian bagiamana?" (Tuturan 2)

Guru: "Hanya bimbingan pagi di sekolah saja atu di luar jam sampean les?" (Tuturan 3)

Guru: "Nggak ada jam tamabahan di luar?" (Tuturan 4)

Guru: "Saya minta kalian benar-benar memanfaatkan waktu tiga bulan ini!" (Tuturan 5)

Konteks: (Data (11) merupakan tuturan guru mata pelajaran Bahasa Indonesia Pemberian pertanyaan dan nasihat oleh guru untuk persiapan Ujian Nasional (UN)

(TTPEV5)

Data (11) meruakan wujud teknik tutur guru mata pelajaran Bahasa Indonesia ketika berinteraksi dengan siswa. Interaksi tersebut berlangsung ketika guru membuka pelajaran di kelas IX B pada tanggal 23 November 2018.

Teknik tutur yang diterapkan guru pada data (11) berupa pemberian pertanyaan kepada siswa. Pemberian pertanyaan tersebut ditandai dengan penggunaan kata apa (Tuturan 1, Tuturan 3, dan Tuturan 4) dan kata bagaimana (Tuturan 2). Pertanyaan tersebut diperkuat dengan permintaan guru kepada siswa yang teragmabar pada kata minta (Tuturan 5). Pertanyaan guru pada data (11) ditujukan untuk seluruh siswa yang dibuktikan dengan penggunaan kata kalian (Tuturan 2). Pemberian 
pertanyaan oleh guru pada data (11) dilengkapi dengan tindakan nonverbal berupa posisi guru di depan kelas sambil berdiri dan tangan kiri guru bergerak ke kanan dan ke kiri (berada di depan perut) sambil berbicara dan pandangan ke seluruh siswa. Artinya, teknik tutur guru pada data di atas bertujuan untuk memotivasi seluruh siswa dengan maksud untuk menciptakan prilaku belajar siswa guna persiapan ujian nasional. Peran guru merupakan salah satu sumber motivasi dalam memengaruhi perilaku belajar siswa (Dimyati \& Mudjiono, 2013).

\section{Teknik Tutur Penarikan Perhatian}

Teknik tutur yang dipaparakan dalam subbab ini adalah cara guru ketika menarik perhatian siswa secara personal maupun kelompok. Teknik tutur tersebut sebagai wujud motivasi oleh guru terhadap siswa dalam menciptakan pembelajaran yang kondusif. Dengan demikian, motivasi dalam pembelajaran berfungsi untuk penyadaran yang terealisasi melalui pembimbingan dan pengarahan terhadap siswa untuk pemertahanan kegiatan belajar melalui kekuatan internal (Long, dkk., 2013). Berikut beberapa data sebagai teknik tutur guru melalui tindakan verbal dan dilengkapi tindakan nonverbal dalam pembelajaran.

(12) Guru: "Jadi kalian bisa meninggalkan pesan singkat melalui takes of your peaper di kertas kecil atau bisa lewat your mobile phone, seperti sending message." (Tuturan 1)

Guru: "Understand what i mind?" (Tuturan 2)

Guru: "Khoimah slipping." (Tuturan 3)

Guru: "Are you slipping?" (Tuturan 4)

Guru: "Are you sliping?" (Tuturan 5)

Guru: "Yes momo." (Tuturan 6)

Guru: "Yes momo." (Tuturan 7)

Guru: "Tetetetet tetetetet." (Tuturan 8)

Guru: "Kalau sudah jam segini anak-anak nguantok luar biasa." (Tuturan 9)

Kontkes: (Data (12) merupakan tuturan guru mata pelajaran Bahasa Inggris yang berupa teguran untuk salah satu siswa kelas VIII C bernama Khoimah melalui nyanyian)

Teknik tutur guru mata pelajaran Bahasa Inggris terlihat melalui kutipan data (12). Data tersebut dituturkan ketika guru menjelaskan materi tentang short message pada tanggal 05 Maret 2019 di kelas VIII C dengan durasi delapan puluh menit.

Data (12) merupakan teknik tutur guru dalam pembelajaran. Teknik tutur pada data (12) dijadikan sebagai tindakan verbal untuk menarik perhatian siswa dalam pembelajaran. Teknik tutur guru pada di atas bertujuan untuk menarik perhatian siswa bernama Khoimah melalui penyebutan nama siswa yang tergambar pada kata Khoimah (Tuturan 3) dan kata you (Tuturan 4, Tuturan 5) sebagai kata ganti orang kedua tunggal. Teknik tutur penarikan perhatian tersebut dilakukan guru melalui tindakan bernyanyi yang digambarkan pada segmentasi kalimat keempat sampai segmentasi kalimat kedelapan. Teknik tutur tersebut dilengkapai dengan tindakan nonverbal dari guru yang berupa pandangan guru ke arah Khoimah dan kedua jari tangan guru di buka (berada di depan perut) dan digerakkan ke kanan dan kiri ketika menuturkan kalimat keempat dan kelima. Artinya, teknik tutur guru pada data (12) bertujuan untuk menarik perhatian Khoimah melalui teguran yang disampaikan dengan cara bernyanyi. Teknik tutur berwujud penarikan perhatian yang dilakukan guru bertujuan untuk menegur Khoimah yang sedang tertidur ketika pembelajaran. Dengan demikian, teknik tutur yang tergambar pada data (12) sebagai salah satu wujud motivasi dari guru untuk menegur salah satu siswa agar meningkatkan minat belajaranya. Wujud motivasi dalam pembelajaran bersumber pada minat siswa (Muhammad, 2016). Berikut data lain yang menunjukkan teknik tutur guru dalam menarik perhatian siswa. Tindakan guru dapat berupa verbal dan dipertegas dengan tindakan nonverbal.

(13) Guru: "Mbak Ruroh!" (Tuturan 1)

Guru: "Ada lagunya mbak Ruroh itu anak-anak." (Tuturan 2)

Guru: "Mbak Ruroh mbak Ruroh sukanya bikin heboh." (Tuturan 3)

Guru: "Itu lagu anak saya sebenarnya, jadi Ruroh sudah ada lagunya ketika di dalam kelas jangan bikin heboh!” (Tuturan 4)

Konteks: (Data (13) merupakan tuturan guru mata pelajaran Bahasa Inggris yang sedang menegur salah satu siswa kelas VIII B bernama Ruroh)

(TTEPR2)

Data (13) merupakan bagian dari teknik tutur guru mata pelajaran Bahasa Inggris yang digunakan untuk berinteraksi dengan siswa dalam pembelajaran. Guru berinteraksi dengan siswa ketika mengajarkan materi tentang recount text pada tanggal 18 Februari 2019 di kelas VIII B.

Wujud verbal pada data (13) merupakan salah satu teknik tutur yang ingin diterpakan guru dalam pembelajaran. Teknik tutur tersebut dibangun guru melalui penarikan perhatian. Penarikan perhatian pada data (13) ditujukan untuk salah satu siswa yang dibuktikan dengan adanya penyebutan nama Ruroh pada setiap tuturan di atas. Teknik tutur berwujud penarikan perhatian dibangun guru melalui tindakan bernyanyi yang tergambar pada segmentasi kalimat ketiga sebagai bentuk verbal. Dengan demikian, guru teknik tutur yang dibangun guru untuk memotivasi salah satu siswa melalui nyanyian agar siswa tersebut merespon dan memperhatikan tindakan yang dilakukan guru. Nyanyian tersebut sebagai wujud teguran dari guru untk 
siswa bernama Ruroh yang ramai ketika pembelajaran berlangsung. Teguran yang dilakukan guru kepada Ruroh dilengkapi dengan tindakan nonverbal berupa posisi guru berada di depan kelas dan pandangan ke arah siswa bernama Ruroh ketika menuturkan data (13). Teguran guru pada data (13) diindikasikan sebagai wujud pemberian nasihat oleh kepada siswa untuk fokus dalam pembelajaran. Wujud motivasi yang dilakukan guru sebagai pendidik dapat pemberian nasihat kepada siswa yang bertujuan menciptakan kondisi belajar (Dimyati \& Mudjiono, 2013). Ada data lain sebagai teknik tutur yang ingin diterapkan guru kepada siswa. Teknik tutur tersebut diwujudkan oleh guru melalui penarikan perhatian siswa.

(14) Guru: "Kelainan pada ginjal karena terdapat albumin dan protein dalam urine." (Tuturan 1)

Guru: "Penyakit ini merupakan wujud dari gejala kerusakan alat filtrasi pada ginjal." (Tuturan 2)

Guru: "Di luar negeri banyak yang membeli ginjal." (Tuturan 3)

Guru: "Mangkane Bu Ari sering ngomog, kemarin banyak kasus penculikan yang diambil apa?" (Tuturan 4)

Guru: "Ginjal." (Tututran 5)

Guru: "Satu ginjal harganya bisa ratusan." (Tuturan 6)

Guru: "Bahkan kemarin ada orang tua dari muncar, ia menjual ginjalnya di Perliman Banyuwangi." (Tuturan 7)

Guru: "Jadi ia menulis dikardus dijual ginjal." (Tuturan 8)

Guru: "Lek kamu kepengin kaya ya silahkan dijual ginjalnya!" (Tuturan 9)

Guru: "Tapi itu tadi efeknya kamunya gak hidup." (Tuturan 10)

Guru: "Jangankan begitu ada gangguan sedikit pada ginjal aja kita sudah

kesakitan apalagi jika tiadak ada ginajl pasti kita tidak hidup."

(Tuturan 11)

Konteks: (Data (14) merupakan tuturan guru mata pelajaran IPA yang berisi tentang penyampaian informasi kepada siswa kelas VIII C tentang fenomena penjualan organ ginjal)

(TTEPA1)

Data (14) merupakan salah satu wujud teknik tutur dari guru mata pelajaran IPA yang digunakan untuk berinteraksi dengan siswa. Interaksi tersebut berlangsung ketika guru menyampaikan materi tentang ginjal pada tanggal 06 Maret 2019 di kelas VIII C dengan durasi delapan puluh menit.

Teknik tutur yang ingin diterpakan guru pada data (14) berwujud penarikan perhatian. Penarikan perhatian tersebut tergambar pada tuturan guru dalam (Tuturan 3, Tuturan 4, dan Tuturan 7) yang berisi tentang fenomena penjualan ginjal. Artinya, teknik tutur yang diterapkan guru pada data (14) dibangun dengan menyampaikan ilustrasi faktual untuk menarik perhatian dan respon siswa ketika guru menyampaikan informasi tersebut. Teknik tutur tersebut sebagai wujud motivasi dari pengaruh guru untuk meningkatkan minat belajar siswa khususnya dalam mempelajari tentang organ ginjal. Gagasan tersebut diperkuat dari hasil penelitian tentang pembelajaran perangkat lunak yang diilustrasikan melalui video tutorial signifikan dijadikan sebagai motivasi untuk meningkatkan pengetahuan siswa (Meij, dkk., 2017).

Berikut ini data yang menunjukkan teknik tutur guru ketika ingin berinteraksi dengan siswa. Interaksi tersebut terjadi dalam pembelajaran Bahasa Indonesia.

(15) Guru: "Ayo kelompoknya Tio maju untuk bermain drama!” (Tuturan 1)

Guru: "Main drama kyok dikongkon opo ae." (Tuturan 2)

Guru: "He sini loh!" (Tuturan 3)

Guru: "Yang lain dengarkan!" (Tuturan 4)

Guru: "Baik wes stop ngomong!" (Tuturan 5)

Guru: "Wes yang lain semua ke sini nanti ini jadi cerminan oh ini kesalahannya disini berarti saya nggak boleh seperti ini, paham?" (Tuturan 5)

Konteks: (Data (15) merupakan tuturan guru mata pelajaran Bahasa Indonesia yang berisi tentang pemberian tugas siswa kelas VIII C untuk praktik bermain drama secara berkelompok)

(TTEPV1)

Data (15) merupakan wujud teknik tuturan dari guru mata pelajaran Bahasa Indonesia ketika ingin berinteraksi dengan siswa. Interaksi tersebut berlangsung dalam pembelajaran tentang drama pada tanggal 06 Maret 2019 di kelas VIII C dengan durasi delapan puluh menit.

Data (15) sebagai wujud teknik tutur guru ketika ingin berinteraksi dengan siswa dalam pembelajaran. Teknik tutur tersebut dibangun guru melalui penarikan perhatian siswa. Teknik tutur berwujud penarikan perhatian dilakukan guru dengan cara memerintah sebagain siswa untuk maju ke depan dan praktik bermain drama secara bergantian. Hal tersebut dibuktikan dengan tuturan guru pada (Tuturan 1) yang bermaksud untuk memerintah seluruh siswa bermain drama. Perintah tersebut sebagai wujud dominasi verbal oleh guru agar siswa mengikuti instruksi dari guru. Bahasa guru merupakan dominasi verbal untuk menggerakkan siswa agar lebih giat belajar (Wicaksono, 2016). Dengan demikian, tujuan guru memberikan perintah tersebut agar siswa aktif terlibat dalam pembelajaran. Salah satu fungsi motivasi belajar sebagai penggerak siswa untuk aktif dalam proses pembelajaran (Sardiman, 2012). Berikut data yang menunjukkan teknik tuturan guru mata pelajaran bahasa Indonesia dalam pembelajaran. Tuturan tersebut dijadikan alat untuk berinteraksi dengan siswa. 
(16) Guru: "Perhatikan!" (Tuturan 1)

Guru: "Nantik rek kelas delapan C, nantik ini kan mau acara perpisahan kelas Sembilan!" (Tuturan 2)

Guru: "Maunya saya kelas delapan C menampilkan satu drama!"

(Tuturan 3)

Guru: "Mulai sekarang sampean tentukan tema dramanya itu!" (Tuturan 4)

Guru: "Kamu cari naskah drama!" (Tuturan 5)

Guru: "Kalau buat sendiri nggak mungkin ya?" (Tuturan 6)

Guru: "Kamu cari di internet!" (Tuturan 7)

Guru: "Pokoknya kamu cari teks drama yang sekiranya kamu mampu memerankannya dan mampu menyediakan propertinya!" (Tuturan 8)

Guru: "Paham?" (Tuturan 9)

Konteks: (Data (16) merupakan tuturan guru mata pelajaran Bahasa Indonesia yang berisi tentang pemberian perintah kepada siswa kelas VIII C untuk bermain drama dalam acara perpisahan kelas sembilan)

(TTEPV2)

Data (16) merupakan salah satu teknik tuturan dari guru mata pelajaran Bahasa Indonesia. Teknik tutur tersebut berlangsung pketika guru menjelaskan materi tentang drama pada tanggal 13 Maret 2019 di kelas VIII C dengan durasi delapan puluh menit.

Data (16) dijadikan sebagai wujud teknik tutur guru ketika berinteraksi dengan siswa. Teknik tutur tersebut dibangun oleh guru melalui penarikan perhatian siswa. Guru menarik perhatian siswa melalui permintaan guru kepada siswa untuk bermain drama dalam acara perpisahan kelas IX yang tergambar pada (Tuturan 3). Permintaan tersebut bertujuan agar siswa lebih tertarik belajar drama. Selain itu, permintaan tersebut dijadikan sebagai penarik perhatian siswa agar menyimak penjelasan dari guru. Permintaan guru pada data (16) merupakan wujud motivasi guru untuk meningkatkan minat belajar siswa.

Ada data sebagai wujud teknik tutur yang digunakan guru untuk memotivasi siswa. Motivasi tersebut dibangun guru melalui penarikan perhatian siswa.

(17) Guru: "Ayo dikerjakan!" (Tuturan 1)

Guru: “Tau nggak bedanya sampean dengan kebo?” (Tuturan 2)

Guru: "Apa?” (Tuturan 3)

Guru: "Nggak ada sama." (Tuturan 4)

Guru: "Lak nggak digertak nggak ngerjakno sampean iku!" (Tuturan 5)

Guru: "Podo koyok kebo lak nggak dipecut yo nggak melaku." (Tuturan 6)

Guru: "Kalau mau beda sampean lebih ngganteng, lebih mulia, ayo wayae ngerjakne yo ngerjakan gak ngerti yo takok gitu!" (Tuturan 7)

Konteks: (Data (17) merupakan tuturan guru mata pelajaran Matematika yang berisi tentang pemberian perintah siswa kelas VII A untuk mengerjakan tugas aritmatika sosial)

(TTEPE1)

Data (17) merupakan wujud teknik tutur dari guru mata pelajaran Matematika. Tuturan tersebut muncul ketika guru menjelaskan materi tentang aritmatika sosial yang berlangsung pada tanggal 11 Maret 2019 di kelas VII A dengan durasi delapan puluh menit.

Data (17) merupakan wujud teknik tutur guru ketika ingin berinteraksi dengan siswa. Teknik tutur tersebut dibangun melalui penarikan perhatian siswa terhadap ungkapan yang disampaikan oleh guru. Ungkapan tersbut tergambar pada (Tuturan 2) dan (Tuturan 6) yang berisi tentang penyamaan siswa dengan hewan kerbau. Ungakapan tersebut disampaikan guru dengan tujuan untuk menarik perhatian siswa agar memperhatikan dan merespons perintah dari guru. Selaian itu, ungkapan tersebut bertujuan untuk menasihati kepada siswa untuk melaksanakan kewajibannya dalam belajar dengan baik. Nasihat merupakan salah satu wujud motivasi yang dilakukan guru sebagai pendidik (Dimyati \& Mudjiono, 2013).

\section{PEMBAHASAN}

Paparan pada sub bab ini berisi tentang pembahasan atas hasil penelitian dari teknik tutur guru ketika memotivasi siswa. Teknik tutur guru untuk memotivasi siswa terbagi atas dua bentuk, yaitu teknik tutur pemberian pertanyaan dan teknik tutur penarikan perhatian. Teknik tutur pemberian pertanyaan dijadikan guru sebagai cara untuk memotivasi siswa agar meningkatkan minat belajarnya. Konsep tersebut diperkuat dengan fungsi pertanyaan dari guru sebagai stimulus untuk meningkatkan kemampuan kognitif dan afektif siswa dalam belajar (Yunarti, 2009). Selain itu, ada teknik lain berupa penarikan perhatian siswa oleh guru yang dijadikan cara untuk memotivasi siswa. Motivasi tersebut bertujuan untuk meningkatkan perhatian siswa dalam belajar. Perhatian siswa menjadi faktor krusial yang harus dikendalikan guru dalam pembelajaran. Salah satu kendala yang dihadapi guru di kelas adalah kurangnya perhatian siswa dalam mengikuti pembelajaran (Hadis, 2006).

Teknik tutur pemberian pertanyaan yang diterpakan guru terdiri atas dua teknik, yaitu teknik tutur pemberian pertanyaan untuk salah satu siswa dan teknik tutur pemberian pertanyaan untuk kelompok. Teknik tutur pemberian pertanyaan digunakan guru untuk meningkatkan ranah kognitif siswa melalui penggunaan kata apa, apakah, piro atau berapa, darimana, 
dan bagaimana. (Bloom, dkk., 1956), ranah kognitif dalam penyelenggaraan pendidikan berfungsi sebagai pengembangan kemampuan peserta didik dari segi pengetahuan dan penalaran atau berpikir. Selain itu, pemberian pertanyaan dapat dijadikan strategi guru sebagai pengatur interaksi dalam pembelajaran untuk menjalin komunikasi dengan siswa. Berdasarkan hasil penelitian di SMA Negeri 6 Makasar, pemberian pertanyaan menjadi metode yang digunakan guru untuk menjalin komunikasi dengan siswa melalui interaksi pembelajaran (Herin, 2017).

Teknik tutur pemberian perhatian sebagai wujud kreativitas guru untuk menarik perhatian siswa dalam pembelajaran. Hasil pengelolahan data statistik yang bersumber pada hasil penelitian hubungan antara krativitas guru dengan prestasi siswa menunjukkan pengaruh positif dalam menentukan prestasi belajar di SMK Bandung (Juandi \& Sontani, 2017). Teknik tutur penarikan perhatian diwujudkan guru melalui tuturan yang dinyanyikan, penyampaian informasi, perintah, dan penganalogian. Tindakan bernyanyi yang dilakukan guru bertujuan untuk menarik perhatian salah satu siswa sebagai target komunikan. Bahasa dalam nyanyian tersebut berisi sindiran untuk meningkatkan antusias dan kosentrasi siswa dalam belajar. Teknik tutur yang berwujud penyampaian informasi dilakukan guru dengan pemberian contoh fenomena faktual tertentu yang bertujuan untuk menarik antusias seluruh siswa. Wujud teknik tutur pemberian perintah berupa instruksi yang harus dipraktikan oleh seluruh siswa dengan materi tertentu.

\section{SIMPULAN}

Teknik tutur guru untuk memotivasi siswa terbagi atas dua bentuk, yaitu teknik tutur pemberian pertanyaan dan teknik tutur penarikan perhatian. Pertama, teknik tutur pemberian pertanyaan yang diterpakan guru terdiri atas dua teknik, yaitu teknik tutur pemberian pertanyaan untuk salah satu siswa dan teknik tutur pemberian pertanyaan untuk kelompok. Teknik tutur pemberian pertanyaan untuk salah satu siswa dilakukan melalui penunjukkan langsung siswa tersebut. Penunjukkan langsung siswa sebagai target komunikan dilakukan guru dengan penyebutan nama siswa dan penyebutan siswa dengan kata ganti orang kedua tunggal. Teknik tutur tersebut dilengkapi dengan tindakan nonverbal guru berupa pandangan guru ke arah target komunikan, jari telunjuk guru mengarah ke target komunikan, dan guru berjalan mendekati target komunikan. Teknik tutur guru berupa pemberian pertanyaan untuk seluruh siswa yang terlibat dalam pembelajaran diterapkan melalui penyebutan kata untuk menunjuk lebih dari satu orang, seperti kelas delapan, kabeh atau semua, ha, kalian, yang cowok, dan yang cewek. Selain itu, teknik tutur tersebut dilengkapi tindakan nonverbal berupa pandangan guru ke seluruh siswa dan posisi guru ada di depan kelas sebagai tindakan yang netral. Kedua, teknik tutur penarikan perhatian diwujudkan guru dalam tuturan yang dinyanyikan, penyampaian informasi, perintah, dan penganalogian. Tindakan bernyanyi yang dilakukan guru bertujuan untuk menarik perhatian salah satu siswa sebagai target komunikan. Bahasa dalam nyanyian tersebut berisi sindiran untuk meningkatkan antusias dan konsentrasi siswa dalam belajar. Teknik tutur yang berwujud penyampaian informasi dilakukan guru dengan pemberian contoh fenomena faktual tertentu yang bertujuan untuk menarik antusias seluruh siswa. Wujud teknik tutur pemberian perintah berupa instruksi yang harus dipraktikan oleh seluruh siswa dengan materi tertentu.

Berdasarkan hasil penelitian yang telah dilakukan terdapat dua saran untuk dijadikan bahan pertimbangan oleh guru dan peneliti bahasa. Dua saran tersebut diuraikan sebagai berikut. Pertama, guru yang berperan sebagai pengontrol kelas dapat menciptakan kreativitas melalui tuturan edukatif agar siswa lebih antusias dalam belajar. Penemuan dalam penelitian ini yang berupa ragam tutur hasil tempaan guru dapat diajadikan sebagai inspirasi dalam menciptakan ragam tutur kreatif dengan tujuan untuk memotivasi siswa. Selain itu, guru dapat menciptakan strategi pembelajaran melalui teknik tutur yang digunakan ketika berinterkasi dengan siswa. Teknik tutur yang dipaparkan dalam penelitian ini dapat dijadikan strategi guru untuk mendorong dan menyadarkan siswa atas perannya dalam pembelajaran. Kedua, perhatian terhadap realitas penggunaan bahasa perlu dilakukan melalui pengembangan penelitian ilmiah. Hal tersebut bertujuan untuk menilik eksistensi bahasa dalam dunia pendidikan khusunya tuturan guru. Adanya keterbatasan jangkauan atas eksistensi bahasa yang tergambar dalam tuturan guru mengakibatkan perlu diadakan penelitian berikutnya. Penelitian ini dapat dilakukan oleh pemerhati atau peneliti bahasa yang disarankan untuk menyoroti hubungan penggunaan tuturan guru dengan latar etnik atau budaya guru khususnya bahasa yang bermuatan motivasi.

\section{DAFTAR RUJUKAN}

Ardayani, L. (2017). Proses Pembelajaran Dalam Interaksi Edukatif. ITQAN: Jurnal Ilmu-Ilmu Pendidikan, 8(2), 187-200.

Dimyati, \& Mudjiono. (2013). Belajar dan Pembelajaran. Jakarta: Rineka Cipta.

Hadis. (2006). Psikologi dalam Pendidikan. Bandung: Alfabeta.

Hamalik, O. (2013). Kurikulum dan Pembelajaran. Jakarta: PT. Bumi Aksara.

Herin, G. (2017). Pola Interaksi Satu Arah dalam Proses Pembelajaran di Kelas XI IPS SMA Negeri 6 Makasar. Jurnal Sosialisasi Pendidikan Sosiologi-FIS UNM, 4(1), 21-24.

Hikmah, dkk. (2015). Peranan Guru dalam Membina Perilaku Siswa Bermasalah pada Proses Belajar Mengajar Sosiologi. Jurnal Pendidikan dan Pembelajaran, 4(12).

Juandi, A., \& Sontani, U. T. (2017). Keterampilan dan Kreativitas Mengajar Guru sebagai Determinan terhadap Prestasi Belajar Siswa. Jurnal Pendidikan Manajemen Perkantoran, 2(2), 130. https://doi.org/10.17509/jpm.v2i2.8114 
Karner, T., \& Kristina. (2016). Emotional State During Learning Situations and Students' Self-Regulation: Process-Oriented Analysis of Person-Situation. Empirical Research in Education and Training, 8(12). https://doi.org/DOI $10.1186 / \mathrm{s} 4046101600388$

Long, dkk. (2013). The Study of Student Motivation on English Learning in Junior Middle School a Case Study of No.5 Middle School in Gejiu. English Language Teaching, 6(9), 136-145.

Marstiyaningtiyas, E. (2014). Pengaruh Reward dan Punishment terhadap Motivasi Belajar Siswa SMP Islam Plus Baitul Maal-Pondok Aren, Tanggerang Selatan. Skripsi tidak diterbitkan. Fakultas Ilmu Tarbiyah dan Keguruan Universitas Islam Negeri Syarif Hidayatullah, Jakarta.

Meij, dkk. (2017). Supporting Motivation, Task Performance, and Retention in Video Tutorials for Software Training. Educational Technology Research and Development, 66(3), 597-614. https://doi.org/10.1007/s11423-017-9560-Z

Muhammad, M. (2016). Pengaruh Motivasi dalam Pembelajaran. Lantanida Journal, 4(2), 87-97.

Redondo, R. E., \& Martin, J. L. O. (2015). Motivation: The Road to Successful Learning. Profile, 17(2), $125-136$.

Sardiman. (2012). Interaksi dan Motivasi Belajar Mengajar. Jakarta: PT Raja Grafindo Persada.

Wicaksono, L. (2016). Bahasa dalam Komunikasi Pembelajaran. Journal of Prospective Learning, 1(2), 9-19. http://jurnal.untan.ac.id/index.php/ip3m

Yunarti. (2009). Fungsi dan Pentingnya Pertanyaan dalam Pembelajaran. Dipresentasikan pada Seminar Nasional Matematika dan Pendidikan Matematika, Jurusan Pendidikan FMIPA UNY, Yogyakarta. 